\title{
Recognising the Various Trends of Globalisation: Inequality in International Economic Relations
}

\author{
By Isaac O. C. Igwe*
}

\begin{abstract}
Globalisation is based on freedom of economic transactions, aimed at making the world a global economic village, as an engine of interconnectedness, growth and increased living standards of all citizens of the world. It is presupposed to be the radical and revolutionary approach of deconstructing unequal economic policy as it affects developing countries. Deconstruction for Derrida is justice, or it is situated between law and justice and will be applied in solving the global economic marginalisation of the developing nations. This treatise will argue economic justice in the light of 'erga Omnes' after John Rawls, for global economic justice, fairness and equity in the distribution of economies, to balance the need for growth in wealth with regards to the deprived developing nations.
\end{abstract}

Keywords: Deconstruction; Developing Countries; Law; Equity; Justice; Fairness; Globalisation; Marginalisation; Distribution; Economic.

\section{Introduction}

The concept of globalisation has been used in diverse contexts and is at the centre of one of the most contentious debates in contemporary intellectual circles. The idea of competing forms of globalisation theory is itself problematic. This is because the term denotes a proposed interpretative framework for understanding the world. Rosenberg opined that undertaking such a study is 'fraught with difficulty'. ${ }^{1}$ It becomes even more difficult when issues of global governance pertain to analysing the problem of 'weak' states. ${ }^{2}$

The problem mostly relates to the economic aspect of the political and governmental dimensions of contemporary globalisation. Its central ideological basis is global capitalism and the relationships between national governments and institutions of supranational governance. After the Cold War and the so called 'triumph' of capitalism, neo-liberal economic development became the order of economic activity across the world. ${ }^{3}$ The International Monetary Fund (IMF), the World Bank, the World Trade Organization (WTO) and the Transnational Corporations (TNCs) have been active in this direction, propagating policies in economic activities across the globe.

Globalisation discourse is fragmented into different aspects of human interaction: economic, political, financial and cultural globalisation, to mention

\footnotetext{
"LL.B. (Hons), B.L. Barrister \& Solicitor, LL.M. (Lond.) Ph.D. (Law), University of London, United Kingdom. Email: isaacigwe@ @otmail.com.

${ }^{1}$ See Rosenberg (2001).

${ }^{2}$ See Fukuyama (2004).

${ }^{3}$ See Fukuyama (1993).
} 
but a few. ${ }^{4}$ To some degree, these sub-concepts represent an acknowledged structure for understanding the term globalisation. The problem inherent in this approach is that one cannot separate them conceptually and empirically, as interrelations exist among the sub-concepts. ${ }^{5}$ Without denying either the existence or importance of the systems commonly described as political and cultural globalization, this chapter will focus on economic globalisation as primarily a synonym for the development and effects of a neo-liberal capitalist world economy over the last fifty years.

Overall, globalisation has introduced serious challenges to the very basis of governance in the world today. The continuous increase of TNCs, Foreign Direct Investments (FDIs), global financial interactions and supranational institutions has taken away some authority held by nation-states and has led many to argue that national sovereignty has been eroded. A critical overview of the globalisation debate argues that the path of global economic development is leading to greater inequality in a world devoid of social justice. ${ }^{6}$ Accordingly, critics have argued that the accumulation of wealth and power by certain capitalist elites at a global level has shown that TNCs are driven primarily by greed and profit at the cost of developing countries. ${ }^{7}$

This writing will attempt to define the term 'globalisation' as it affects the freedom of economic transactions through making the world a 'global economic village'. This implies that globalisation is an engine of interconnectedness and growth that brings increased living standards to the Third World but this writing will argue that globalisation is a Western framework, structured and designed to subjugate the economic lifeline of the Third World, such that the North becomes richer while the South remains poor. The approach taken is critical of world economic process and pessimistic about the slim chances of regulation of a fair international economy. It will conclude by making the case for a radical and revolutionary deconstruction of this unequal economic policy as it presently affects the developing countries.

\section{Historical Structure}

The literature of capital flows from the core rich to the periphery poor countries, otherwise known as globalisation, dates back to before the end of nineteenth century. As now, there is vigorous contention as to whether the lending or borrowing countries benefit most. Early Marxists like Hobson $(1902)^{8}$ and Lenin $(1917)^{9}$ conceived the idea as a continuation of the strategic accumulation of wealth by the core rich nations. They perceived that the industrialised nations faced overproduction and decline in rates of profit and looked for foreign markets

\footnotetext{
${ }^{4}$ See Castells (1996) (1997) (1998).

${ }^{5}$ See Held \& McGrew (2002); see also Brawley (2003).

${ }^{6}$ See Vandana (2004).

${ }^{7}$ See Bello (2002); see also Amin (1974).

${ }^{8}$ See Hobson (1902).

${ }^{9}$ See Lenin 1917.
} 
through colonial expansion or subtly by economic domination in the form of foreign investment. This line of argument later became the basis for 'dependency theory'. ${ }^{10}$

Openness in trade started before World War One. This was an age, prompted by various technological advances, of liberal trade, a considerable global free movement of people and uninhibited capital movement. It brought remarkable economic growth and prosperity. The Gross Domestic Product (GDP) per head at this period, according to Angus Madison rose at a rate of 1.3 percent a year in the world between 1870 and $1913 .{ }^{11}$ Nonetheless, victims of colonialism like Africa and Asia did not benefit as others from the rise in prosperity. The first globalisation period, ruined by World War One, led to the economic disarray of the interwar period. The US failed to share costs of the war, UK and France became economically weak, there was bitterness between Germany and France, while the rise of Russian communism did not help issues, so the first liberal order failed. $^{12}$ The process of globalisation is not new but the term 'globalisation' is new.

Officially, globalisation did not in the strict sense of the word start until the $19^{\text {th }}$ century. Although the first era of globalisation could be argued to have started between 1870 and 1913, it was not officially globalisation per se, but a process which cannot be properly worded as such. That era could be properly described as the era of liberal trade order or economic openness. The process started from different places and in different ways but all culminated to jumpstart globalisation. Similar events are the age of European exploration, the slave trade, the expansion of Islam, the Great Depression, the Industrial Revolution and the technological revolution.

The history of globalisation has become the subject of ongoing debate and is not the essence of this writing, which focuses on the unequal policies of economic globalisation as demonstrated by the Bretton Woods institutions for the past 50 years. The second era of globalisation dates back to the nineteenth and early twentieth century. The classical work of Karl Marx and Friedrich Engels, ${ }^{13}$ and sociologists such as Saint Simon and Augustus Comte recognised how modernity was integrating the world. ${ }^{14}$

It was not until the 1960 s and early 1970s that the term 'globalisation' achieved wide fame among academics and economists when large US multinationals became operational. Theorists began to argue that firms needed to become global instead of duplicating branches in multiple national-scale operations. By the 1990s, this process was referred to as 'globalisation' and the term entered academic, management and major business literatures.

Kenichi Ohmae argued that globalisation at such a solid level might become a challenge for business towards the end of twentieth century. ${ }^{15}$ Another academic

\footnotetext{
${ }^{10}$ See Furtado (1965); Prebisch R (1950).

${ }^{11}$ Maddison (2003).

${ }^{12}$ Wolf (2004) at X-Xviii.

${ }^{13}$ See Marx \& Engels (1980).

${ }^{14}$ See Holton (1998).

${ }^{15}$ See Ohmae (2004).
} 
contribution in the realm of social and cultural theory was most notably Marshall McLuhan's media- cantered idea of the 'global village.' ${ }^{, 16}$ This was based on finding a way in which modern expanding global society could integrate with the new forms of communication. There were also many other contributions to academic literatures in the area of political economy and social services with regard to post-war international economic development and politics.

These academic theories were drawn on in an argument based on a 'development-as-modernisation' paradigm with a sceptical view towards the new Bretton Woods institutions in relation to the Third World. ${ }^{17}$ Some of these arguments were derived from the social, political and philosophical theories of Marx, Weber and Durkheim. The proponents of globalisation theories in this dimension were Andre Gunder Frank and other dependency theorists, who maintained that the developing nations were subjected to a state of underdevelopment by the industrialised capitalist world. ${ }^{18}$ Frank theorised that if a country's economic strength is determined by its colonial history it certainly will control its global power. ${ }^{19}$ He argued that when development is export oriented, it creates imbalance and weakens the developing world. ${ }^{20} \mathrm{He}$ frowned at the notion of 'world system' and suggested it should be rightly called 'single world system', based on the economic domination of the industrialized nation. He argued that the world system was created only in the $4^{\text {th }}$ millennium BCE which witnessed improvements in human culture and stood as the beginning of the Bronze Age and Writing. ${ }^{21}$ In Gunder Frank's early work he sees underdevelopment in terms of a chain of exploitative metropolis-satellite relationships wherein:

... at each point the international, national and local capitalist system generates economic development for the few and underdevelopment for the many. $^{22}$

By the same token, Immanuel Wallerstein's 'world system analysis' from a Marxian viewpoint argued that the capitalist world is described by a coreperiphery relationship and that the capitalist system has overtaken the world in the twentieth century. ${ }^{23}$ Wallerstein criticised world system as a global economic structure that redistributes resources from the underdeveloped raw materialexporting world (periphery) to the developed (industrialised) nations through the market, the system by which the developed world exploits the underdeveloped. ${ }^{24}$

\footnotetext{
${ }^{16}$ See McLuhan, (1962); McLuhan (1964) at.3; McLuhan (2003) at 6.

${ }^{17}$ The new Bretton Woods is the institutional troika which includes the World Trade Organisation, the International Monetary Fund and the World Bank which was created to channel resources to the developing nations in order to strengthen the liberal infrastructure.

${ }^{18}$ See Frank (1979).

${ }^{19}$ See Frank (1967).

${ }^{20}$ Ibid.

${ }^{21}$ Immanuel Wallerstein contrasted Frank's opinion and said that the world system was actually formed at the beginning of the $16^{\text {th }}$ century; See Wallerstein (1980) at 347-357.

${ }^{22}$ See Frank (1969) at 7-8.

${ }^{23}$ See Wallerstein (1979). For further similar argument on the same subject, see Wallerstein (2004) at 23-30.

${ }^{24}$ See Wallerstein (1980).
} 
Wallerstein argued that world system is a framework of developed nations competing amongst themselves to gain world resources, economic dominance and hegemony over the poor countries. They come into the limelight when they achieve economic dominance in the form of productivity dominance, trade dominance and financial dominance. ${ }^{25}$ For Wallerstein, the capitalist world economy was that in which production was constantly expanded so that profits could be made, and producers innovated to expand the profit margin. ${ }^{26}$ Expounding on this, Wallerstein made it clear that capitalism did not necessarily mean profit margin by persons or firms when he stated that:

" [...] We are in a capitalist system only when the system gives priority to endless accumulation of capital. Using such a definition, only the modern world-system has been a capitalist system. Endless accumulation is quite a simple concept: it means that people and firms are accumulating capital in order to accumulate still more capital, a process that is continual and endless". 27

Before this time, Wallerstein defined capitalism as 'a system of production for sale in a market for profit and appropriation of this profit on the basis of individual or collective ownership. 28

Globalisation actually gained influence following the collapse of state socialism and the consolidation of capitalism worldwide when public awareness intensified in the 1990s. However, the sovereign states in the 1990s were constrained by risks and uncertainties. They perceived the era with an attitude of global market expansion. This was substantiated by the end of the Cold War and the 'triumph of free-market capitalism'. ${ }^{29}$ The process accelerated through the 1990s as globalisation became commonplace and generated controversies among academics and theorists.

\section{Scepticisms about Globalisation}

There are numerous opinions denying that today's trends of globalisation represent anything totally new. The argument is that the phenomenon is not new as it began at least several centuries ago, with some considerable universal openness at the peak of the international economy prior to the 1914 liberal economic order. But the terms of world trade, the functioning of the financial system via the gold standard, and every other significant aspect of the pre-1914 economy were imposed and maintained by European states. ${ }^{30}$ Sceptics like Hirst and Thompson argue that the present international economy and interdependence is less open. In

\footnotetext{
${ }^{25}$ Ibid.

${ }^{26}$ See Peet \& Hartwick (1999).

${ }^{27}$ See Wallerstein (2005) at 23-24.

${ }^{28}$ See Wallerstein (1979) at 66.

${ }^{29}$ See Fukuyama (1993).

${ }^{30}$ See Held \& McGrew (2203).
} 
fact, they argue that the international economy was considerably more open in the pre-1914 period than it was at the end of the twentieth century. ${ }^{31}$ Held argues that trade has grown, post 1914, as the pattern of trade has changed, especially among Western industrialised countries. ${ }^{32}$

The shift is focused on the liberalisation of international limitation on the flow of capital, money and other financial activities, consonant with trade liberalisation. At the centre of this is the ideological basis of coexisting global capitalism and supranational institutions. The concept of globalisation is described as unsatisfactory, for it triggers the question of what it is that is 'global' about it. ${ }^{33}$ The 'global' is often addressed as self-government, above the control of nations, coming from the most powerful nations, combined with their regulatory regimes. ${ }^{34}$ The United States emerged as the dominant world power after World War II, controlling the global economy through its strong influence on the international economic institutions. Although about fifty years of international development cooperation have passed, elimination of poverty remains a global challenge.

Hirst argued that if 'the global' cannot be interpreted literally as a universal phenomenon, then the concept will at best be a synonym for Westernisation. ${ }^{35}$ Accordingly, globalisation should not be construed as the emergence of a harmonious world society or a free process of universal integration where different cultures and civilizations converge and interrelate.

This is because growing interconnectedness not only creates conflicts among nations but encourages economic and political dichotomy. Moreover, it is informed by the fact that a substantial proportion of the world's population does not benefit from globalisation, especially the developing nations like Africa, Latin America, Caribbean and East Asia. It is a divisive system and a highly controversial process.

The internationalisation of global economic and political cohesion is contingent on the policies and preferences of industrialised nations like North America who are able to meet the conditions requisite for a free international order. ${ }^{36}$ This argument means that without American hegemony, the liberal world order of intensification of international interdependence cannot be realised. ${ }^{37}$ Globalisation can in no way stand as a newly created world order, and is rather a continuing 'imperialism without colonies, ${ }^{38}$ or a 'globalised nationalism, ${ }^{39}$

\footnotetext{
${ }^{31}$ See Hirst \& Thompson (1966) at 2.

${ }^{32}$ See Held (2004).

${ }^{33}$ See Hirst (1997).

${ }^{34}$ See Hirst \& Thompson (1996).

${ }^{35}$ Ibid.

${ }^{36}$ See Waltz (1979).

${ }^{37}$ See Gilpin (1987).

${ }^{38}$ See Magdoff (1972).

${ }^{39}$ See Douzinas (2000) at 212.
} 


\section{The Dialectics of Globalisation}

Dialectics refers to the study of systemic contradictions. It is a process of searching for the innate disposition within a system which produces its own disagreements pending the time it can no longer sustain and recreate itself without a radical transformation. In terms of a capitalist socio-economic system, the contemplation of transformation has predominantly occupied the space in Marxist literature. The point is that the world capitalist system has remained inelastic to the wind of change brought in by its own mechanisms of reformation - 'globalisation'. Some writers have proposed a world system of capitalist development which creates asymmetrical characteristics of core and peripheral areas.

These variations are described as dialectical results of the contradictions which gave rise to reactions from neo-Marxist writers like Samir Amin, ${ }^{40}$ Ernest Mandel, ${ }^{41}$ and Harry Magdoff ${ }^{42}$ who similarly identified the world economic system as being at a monopoly capitalism or competitive imperialist stage. ${ }^{43}$ The United Nations' first development decade was declared by 1950 with decolonisation in full flow. As a result the problem of global poverty and inequality became internationalized and a known issue in international political theory. $^{44}$

Apparently, the New International Economic Order (NIEO) was represented in international relations as a reaction by Third World States to their perceived economic and political vulnerability. However, this move was misconstrued as a hidden agenda of the South to create a new international political order as a result of the conflicts among the Southern states' leaders. ${ }^{45}$ Nonetheless, Hoeffmann, ${ }^{46}$ an international political theorist, at some point addressed the demand for a NIEO in the context of Rawlsian justice theory in international relations and idealistically used the views of Michael Walzer's 'just and unjust wars ${ }^{, 47}$ Conventional theorists of international justice are of the view that justice as between states is clearly shown by the principles of international law that are impartial and impartially applied. Rawls seeks impartiality in his theory of justice. ${ }^{48}$ He believes that social and economic inequalities are to be handled in a way that will create the greatest advantage to the least advantaged under the conditions of fair and equal distribution in available opportunities. ${ }^{49}$ In this context, the least advantaged means the developing and least developed countries (LDCs), who should be given the greatest economic benefits through impartial economic policies that would ensure balanced economic growth for all participating nations of the world.

\footnotetext{
${ }^{40}$ See Amin (1977).

${ }^{41}$ See Mandel (1976).

${ }^{42}$ See Magdoff (1978).

${ }^{43}$ See Chase-Dunn (1991).

${ }^{44}$ See Brown (2002).

${ }^{45}$ See Thomas (1997). See also Brown (2002).

${ }^{46}$ See Hoeffmann (1981).

${ }^{47}$ See Walzer (1992).

${ }^{48}$ See Rawls (1971).

${ }^{49}$ Rawls (1971) at 302.
} 
Ordinarily, there may be disagreements among commentators and international lawyers using Rawls' 'A Theory of Justice' in international scope as Rawls' contribution was structured for domestic legal frameworks. ${ }^{50}$ In any case, international lawyers and commentators have applied Rawls' work in the international strata. They have argued that every transnational relationship demands justification in the conditions attached to domestic political reasoning. They have concentrated on political reasoning for the normative approval of income distribution amongst those states that have so much and others that have so little. ${ }^{51}$ Rawls' intent is to balance the need for growth in wealth with regard to the deprived part of a society. ${ }^{52} \mathrm{He}$ argues that it may be permissible to create greater social wealth but a system of inequality will be too harsh to be supported by argument as fair. ${ }^{53}$ Although Rawls' theory of justice has been subject to criticism, ${ }^{54}$ he tried to provide the principles of justice as a rationally dynamic and socially just mechanism that would contribute to growth.

Though the American-led Bretton Woods managed world economy was supportive of free markets and of the internationalisation of capital, it was nevertheless a period of 'embedded liberalism'. The term was coined by John Ruggie in his article $^{55}$ and the term is used in Polanyi's book, The Great Transformation $^{56}$ where he argues that before capitalism the 'market' had always been embedded in the society.

His assertion was informed by the fact that prior to capitalism, the market operated as a system of distribution and reciprocity determined by the rules of the particular society. However, capitalism created artificial goods like land, money and labour and put them into the market to be sold and supplied at relative market demand. 'Embedded liberalism' refers to 'market liberalism' and means the liberalisation of the market and state intervention in the market. This idea was based on the belief that a self- regulating market is more profitable than state intervention in the market. A typical example of 'embedded liberalism' is modern globalisation. This is an international pressure to liberalise every domestic and global market by imposing the removal of trade tariffs, privatising state services and reducing the strength of labour laws for greater wage flexibility. The reason behind all these is to create a single world regulating market.

Contemporary globalisation is an embedded mechanism, dependent on the regulation of 'artificial goods' by the international organizations such as the United Nations, IMF, World Bank and WTO. These are in principle multinational organisations which enjoy common features of weighted vote and veto powers topped up by the United States. Both the IMF and World Bank allow exclusive veto power to the US. Although the US does not have veto power in the WTO, it

\footnotetext{
${ }^{50}$ See Pogge (1989) at 247. Instead of Rawlsian original individualism, Pogge imagined a globalised position where every individual would be represented by means of a worldwide method of justice as fairness.

${ }^{51}$ See Mandle (2000). See also Sen \& Foster(1997).

${ }^{52}$ See Rawls (2001).

${ }^{53}$ See Rawls (2005).

${ }^{54}$ See Blair (1988). See also Sen (1991).

${ }^{55}$ See Ruggie (1982).

${ }^{56}$ See Polanyi (1944).
} 
enjoys such privilege in practice as it has the greatest consumption potential. Similarly, the US enjoys no exclusive veto power in the UN, but its exclusive power in the World Bank and the IMF gives its UN veto a weighted vote.

By and large, the UN can be perceived as the global adjudicator of these 'artificial goods' of land as it has the final say on territorial disputes, apparently controlled by the United States. In the same vein, the WTO, World Bank and the IMF are the adjudicators of money and labour as they dominate their members in running their economies and labour laws.

After World War II (1946-1948), many countries deliberated for the establishment of a trade agreement later called the General Agreement on Tariffs and Trade. These countries that came together to form the GATT, known collectively as the contracting parties, did not intend it to be an actual organisation, ${ }^{57}$ but merely a temporary agreement. ${ }^{58}$ While creating the GATT, the contracting parties deliberated for the establishment of an International Trade Organisation (ITO) ${ }^{59}$ to strengthen the GATT. The ITO was created in a bid to become the third arm of the Bretton Woods economic order with the International Monetary Fund (IMF) and the World Bank. ${ }^{60}$ The contracting parties, through a conference in March 1948 in Havana, Cuba created a Havana Charter that did not stop at regulating trade between countries, but extended to restrictive trade practices, rules on employment and foreign investments. ${ }^{61}$ The GATT was used in place of the ITO because the ITO was rejected by the US congress on grounds that it conflicted with their domestic policy.

From the outset, the GATT was designed as a partisan instrument, formed to liberalise areas that would enhance the US post-war economy while protecting agriculture. $^{62}$ The GATT succeeded because it was an institution among others that served to gather together American power and the economic system that served its interests best. Its objectives were narrow and specific compared to the widely framed development, reconstruction and full employment agenda of its predecessor the ITO. ${ }^{63}$ Yet the contemporary advent of the GATT was described in a manner that separates its formation from political purpose. The underlying argument for the institution of the GATT is for a return to both liberalism and liberalisation. It was argued that without multilateral trade, protectionism and insecurity would increase. If protectionism goes without check, countries will be susceptible to pursue bilateral or regional economic objectives which may lead to fragmentation of the world economy and the features of the 1930s interwar economic depression could resurface. ${ }^{64}$

\footnotetext{
${ }^{57}$ See Jackson Testimony in the World Trade Organisation and United States Sovereignty Hearing Before the United States Senate Committee on Foreign Relations, 994 WL 266992, June 4, 1994.

${ }^{58}$ See Hudec (1999).

${ }^{59}$ See Jackson (1994).

${ }^{60}$ See Stichele (1996).

${ }^{61}$ Jackson (1992).

${ }^{62}$ See Brown (1950).

${ }^{63}$ See Final Act of the United Nations Conference on Trade and Employment (1948).

${ }^{64}$ For an example of the case made for both the formation of the ITO and the GATT, see Wilcox (1949).
} 
The development dimensions since the birth of multilateral trade regulation through the ITO and GATT differ in ideological dispositions and economic interests. Nonetheless, the story is portrayed neutrally to encourage participation in and continuity of the system. As opposed to the GATT, the ITO was committed to build a social market globally since it was obligated to find a common ground between the full employment regulation and labour standard ${ }^{65}$ that had become a concern of the agenda through the industrial world and the developmental needs of the developing countries in the new global order. ${ }^{66}$ The Havana Charter was the defining moment, recasting the relationship between trade, development and employment. ${ }^{67}$ Its extinction created a lacuna in the structure of the post-war institutions of global governance in five analytical areas: labour rights and standards, dispute settlement and interpretation, the international price for primary commodities, the regulation of transnational business and on governments themselves.

By contrast, the GATT had only residues of the non-liberal characteristics that had stopped the ITO from becoming an institution. The issue of labour standards was not contained in the GATT, 'except for the provision in Article XX (e) that permits governments to ban trade in goods produced using prison labour, GATT says nothing about labour standards, ${ }^{68}$ nor was it included in the WTO. Under the Havana charter, members are given authority to make legal and binding interpretations of the charter. This was essential because such power would not only expedite the operation of the institution, but besides, it would enhance the interests of the agreement, allowing it to develop and modify along with the changing international economy. Ordinarily, the express provision of such power to make legal and binding findings in an international organisation is preferred to those provisions which can only 'recommend' compliance.

The ITO in its dispute settlement or interpretation carries a binding treaty even when its members turn down its decision on grounds that they are not conducive for them. ${ }^{69}$ Non-compliance with the binding treaty obligation carries sanctions, the main penalty being in the form of trade concessions. ${ }^{70}$ Conversely, the GATT lacks such binding interpretative powers. The GATT had no requirement under the norms of international law settings as opposed to the ITO where every nation is entitled to use its dispute resolution procedure exclusively and can refer to the International Court of Justice on certain matters. ${ }^{71}$ Such appeal provision to the court was imperative, as expounded in the words of Clair Wilcox, the Vice-chairman of the US delegation to the Havana conference: 'It provided for the development of a body of international law to govern trade relationships'. ${ }^{2}$

The inclusion of the formal binding interpretation would serve as a check to the countries; otherwise the GATT's dispute settlement mechanism would be

\footnotetext{
${ }^{65}$ See Kock (1969).

${ }^{66}$ See Havana Charter, Atr.1 and Art 55.

${ }^{67}$ See Havana Charter, Art.1, Art 2; and Art. 10-11.

${ }^{68}$ See Charnovitz (1995) at 171

${ }^{69}$ See Jackson (1989) at 90.

${ }^{70}$ Ibid.

${ }^{71}$ See Havana Charter, Art. 96

${ }^{72}$ See Havana Charer at 93.
} 
voluntary or disregarded without penalty and could obliterate the chances of forming new legal norms. For instance, a contracting party was not obligated to admit an amendment which it kicked against. ${ }^{73}$ By and large, the end of the ITO meant a problem to the developing world since its ambitious framework to stabilise the international price of primary commodities met a sudden death. Moreover, the failure of the ITO prevented the possibility of producers working together to market primary commodities. In the area of investment rules, the Charter in Art. $52^{74}$ provided that new investment can only be allowed into a host country on condition that erected barriers are removed and a code must be enforced regulating the restrictive practices of international trade. The point here is that investors' rights would not be allowed to override the responsibility of the host country. That is to say, no member is prevented from enforcing any national law to prevent 'monopoly practices'. Furthermore, the Havana Charter applied to both governments and private firms who indulge in restrictive practices that limit the liberal ideal of non-discriminatory trade practices. ${ }^{75}$ Thus the ITO provided anticompetitive practices which were clearly omitted in the GATT provisions. ${ }^{76}$

Protectionism was undoubtedly excluded from GATT procedures and does not form a part of its consideration under GATT's dispute mechanism. ${ }^{77}$ In fact, under the GATT, governments are only answerable to international regulation, not private authority or multinationals and therefore were silent on the issue of monopolistic practices by overpowering transnational corporations. Indeed, the ITO charter contained a provision for social dumping ${ }^{78}$ which means the practice of selling exports below what the costs of production would be if international labour standards were followed. This provision received attention at the UN Conference on Trade and Employment, as well as at the world trade union conference held in London in 1945. Also, in the dimension of human development, the Charter provided that long term loans should be made available to colonial countries for economic and social development on condition of observing internationally agreed principles. It called for the International Labour Organization (ILO) and the ITO to be in close cooperation and consultation with each other on matters of common interest. ${ }^{79}$ This close cooperation is in partial fulfilment of Roosevelt's wartime promise ${ }^{80}$ that the ILO would play an essential role in rebuilding a 'stable international system of social justice for all peoples. ${ }^{, 81}$

Most of the academic writings on the history of the International Trade Organization deal with the negotiation of the Havana charter, which could have

\footnotetext{
${ }^{73}$ See Jackson (1989) at 94-103.

${ }^{74}$ See Havana Charter, Article 52.

${ }^{75}$ See Havana Charter, Art. 20-21, 22

${ }^{76}$ See Havana Charter, Art.56.

${ }^{77}$ See GATT, Article xxiii.

${ }^{78}$ See Havana Charter, Art. 34

${ }^{79}$ See Havana Charter, Art. 7.

${ }^{80}$ In 1941, Franklin D. Roosevelt and Winston S. Churchill met off the coast of Newfoundland and agreed that the principles of multilateralism would be the background of the new international order which would allow the well-being and employment prospects for all to be increased at an equal pace. See Atlantic Charter 1941.

${ }^{81}$ See Alcock (1971) at 169.
} 
led to the formal establishment of the ITO. Wilcox portrayed the consequences of mixing liberalisation with economic interest and political ideology by giving an account of the century that preceded the First World War as peaceful and stable, where goods moved 'with relative freedom between the nations of the world' ${ }^{82}$ Wilcox associated the pursuit of liberalisation with the accentuation of 'progress' and its result with the 'freedom' of the nineteenth century. He used disease as a metaphor for the consequences of changing and stopping the process of liberalisation. He used the illustration of extreme poverty and misery to juxtapose liberty and prosperity to give credence to his message.

Wilcox proposed to the US and its allies, the biggest vested interest in the post-war order, to pursue liberalisation as an important factor for peace building in the post-war period. ${ }^{83}$ Although Wilcox's account is not without flaws, such as his claim that peace preceded the First World War; there were some traces of known conflicts like the Napoleonic wars (1799-1815), American civil war (1861-1865) and other civilian wars and rebellions. On his claim that goods moved freely prior to World War One, British agriculture was heavily protected, except for the repeal of the Corn Laws in 1846, after which protectionism continued. Similarly, Germany and Sweden protected their agriculture in the $19^{\text {th }}$ century; Britain, France and Germany protected their infant industries and as a measure of protectionism at this time, the USA's tariffs were routinely high ${ }^{84}$ and extended to foreign investment in banking, shipping and mining which was highly regulated. ${ }^{85}$ However, it is not criticism of Wilcox's account that is important; but his compelling message that added weight to the call to revert to liberalism, the spring board to a new era of liberalisation which must be distanced from partisan interests. Wilcox's most compelling logic is the necessity to avoid a return to the 1930s economic depression and the possibility of resurgence of another world war. $^{86}$

The consequences of not reconstructing the trade regime led to the development of an argument that gathered support for the multilateral agenda that preferred liberalisation which formed the historical basis of the GATT. The criticisms about persistent protectionism, bilateralism and regionalism resulted in a call for increased free trade as certain GATT/WTO practices were deemed unfair, undemocratic and non-transparent. But the GATT's partisan nature, coupled with the way it evolved, caused trade negotiations from the outset to be highly contested and thus likely to result in crisis or collapse. ${ }^{87}$ Albeit, crisis discourse was created to abate this condition but what emerged was a sort of political control where trade negotiations are framed in a way consistent with the conclusion of bargains by reminding the parties the consequences of interrupting trade liberalisation. ${ }^{88}$

\footnotetext{
${ }^{82}$ See Wilcox (1949).

${ }^{83}$ Wilcox (1949) at 3-10, 12-13.

${ }^{84}$ See Irwin (2001).

${ }^{85}$ See Chang (2007).

${ }^{86}$ See Viner (1947).

${ }^{87}$ See Wilkinson (2006).

${ }^{88}$ See Wilkinson (2009).
} 
In the ITO, major decisions by the member states would be based on 'sovereign equality' rather than weighted-voting ${ }^{89}$ as in the case of the IMF and the World Bank. Democratic governance at the international level demanded recognition and extension of majority voting rather than elite control by the few. At the World Bank, the US had a fifth of the voting power, the EEC almost a quarter and OECD nations close to 60 percent. Capital rich nations comprised 16 percent of the membership in 1982 but four times the votes. It is not difficult to see why, as a consequence of these voting arrangements, after the disappearance of the ITO, the World Bank and the IMF have supported the rights of foreign investors and have condemned international behaviour that extends host countries' rights to maintain control over their resources. ${ }^{90}$ The ITO was inspired by the fact that no country nor powerful business lobby nor trade union ever wants to be tied to an inflexible set of rules that does not let countries protect themselves from the shortterm difficulties of adjustment that lead to loss of jobs or markets or both when faced with sharp changes in the business arena. No doubt, the brief existence of the ITO brought progress to the world trading order. The ITO influenced the single largest tariff cut over some $\$ 10$ billion trade prior the war prices consisting of 45,000 concessions made by the US to cut tariffs up to 50 percent. As a result, the value of world trade shot to some 360 percent from 1947 to $1966 .^{91}$

However, the ITO was replaced by the GATT and was succeeded by the WTO in 1994, which came with many policy changes in global trade regulation. Originally, the GATT was formed with the specific purpose of stimulating US post-war economic growth. Although it was designed to offer a measure of assistance in the reconstruction of the European allies, the nature of the trade liberalisation it pursued revolved around these two specifics. From the start the liberalisation agenda in industrial goods proved beneficial to the US and Europe while it remained of less value to the GATT's early contracting participating countries such as Chile, Sri Lanka, Brazil, Southern Rhodesia (now Zimbabwe), Burma, Cuba, and Pakistan. These original GATT contracting parties were more inclined to liberalise agriculture and tropical produce which have remained heavily protected areas. $^{92}$ The combination of political bargaining among states of vastly different capabilities and exchange as the mechanism of liberalising trade has produced bargains that are of significantly different value to participating states. When these countries requested a better trade policy, they would be coerced to agree to new concessions in return. Based on this premise and coupled with underlying power inequalities between participating nations, there have been continuous asymmetries in outcome that have adversely affected the GATT rounds. The epitome of institutionalisation of 'unembedded' liberalism is represented by the WTO Uruguay Round GATT agreement of 1994, in particular the protocols to 'trade-related investment measures' (TRIMs) and 'trade-related

\footnotetext{
${ }^{89}$ Weighted-Voting is a system where the preferences of some voters are given more importance than those of others. The interest in the voting system is measured not in terms of vote but the concept of political power.

${ }^{90}$ See Lipson (1985) at 90-91.

${ }^{91}$ See Dur (2007).

${ }^{92}$ See Brown (1950).
} 
intellectual property rights' (TRIPs). These protocols undermine the sovereign authority of states, especially developing countries, in relation to regulating foreign investment and external trade for development. ${ }^{93}$

In the absence of fundamental departure from existing ways of regulating multilateral trade, few chances exist to meet development gains for all participating countries, especially the poor countries. Anything less than a balanced regulating multilateral trade will be at best a patched-up problematic system. The fact is that there exist some institutional barriers to the reform of the multilateral trade system to encourage a greater development dimension in the WTO. The liberalisation agenda of the WTO is partisan and largely serves the interests of the developed nations in the way the organisation is structured and the manner in which liberalisation is pursued.

\section{Moves towards a Truly Globalised Economy}

At present, the global economic process remains a far cry from being purely 'global.' Rather; international trade concerns such as financial circulation and investment are focused in America, Japan and Europe. These industrialised nations have the economic capability to determine global financial markets and other ancillary economic dispositions. ${ }^{94}$

The term 'globalisation of law' refers to 'the degree to which the whole world lives under a single set of legal rules. Such a single set of rules might be imposed by an international body adopted by global consensus or arrived at by parallel development in all parts of the globe. ${ }^{95}$ The emergence of various actors in the financial markets that foster financial flows has made accountability difficult in such numerous types of transactions. Some of these actors have defied state control through the use of sophisticated technologies. This trend, which is found both at the national and international level, has created considerable obstacles to the efficient regulation of the financial market. Nonetheless, the emergence of truly global markets is signalled further by an increase in the issue of private bonds and equities and by the fact that interest rates are now determined globally rather than nationally. ${ }^{96}$

Another major contributor of financial flows is foreign direct investment (FDI). This is a faster mechanism that has overtaken the imprints of international trade. It is the shifting of capital across national borders in a way that allows the investor to regulate accrued assets. This usually takes the form of investment or production facilities in the recipient country. ${ }^{97}$ It is different from equity investment that may go beyond borders but carries no such control.

\footnotetext{
${ }^{93}$ See Watkins (1992).

${ }^{94}$ See Hirst \& Thompson (1966) at 2-3.

${ }^{95}$ See Dasgupta.

${ }^{96}$ See Perraton (1997) at 265-271.

${ }^{97}$ See Held, McGrew, Golblatt \& Perraton (1999).
} 
The process of FDI started operating across Europe in the medieval period and was an essential evolutionary stage of European colonialism. ${ }^{98}$ Nineteenth century imperialism operated in the form of equity investments while FDI stood as a tool for the internationalisation of production. ${ }^{99}$ The trend of FDI flows increased mostly after the Second World War with the US companies as the primary source. The period between 1945 and 1960, the US FDI activities in the world stood at three-quarters. The FDI in the 1960s and 1970s was however sourced mainly from Europe and Japan. In the $21^{\text {st }}$ century, the Asian and Latin American economies have equally become sources of FDI, showing the increase of multinational corporations and transnational corporations.

The UNCTAD in 1999 stated that:

"Total FDI reached US $\$ 644$ billion in 1998 - a gain of 39 percent over the previous year, driven by cross-border mergers and acquisitions. The share of FDI inflows to developing countries in 1998 was 42 percent, up from 18 percent in the mid 1980s. However, of the total FDI going to developing countries and Eastern Europe in the 1990s more than 80 percent went to only 20 countries. More than one quarter went to China alone. In 1998, the top five developing countries receive 55 percent of total FDI inflows to the developing world." 100

No doubt FDI has contributed to the economic growth of the countries where it is properly implemented. However, to all intents and purposes, it has not contributed to a uniform global development approach as its true nature speaks for itself. The influence of FDI in the global economy has grown strongly in recent times.

The second manifestation of a shift in the international order has been through the operations of transnational corporations (TNCs). When a company engages in importing goods, it is engaging in transnational activities. If it engages in lobbying foreign governments about trade, it becomes a transnational political actor. At the time this company extends its operations across the borders of their home countries in the form of branches or subsidiaries, it becomes a transnational corporation (TNC). ${ }^{101}$ According to some theories, it is required that the large company's activities shall be up to fifty per cent or above its total turnover and it must have a wide scope of activities in many countries. ${ }^{102}$ Some of these 'extensive activities' have been identified by Hirst and Thompson as activities stretched towards independent and specialised sectors, aimed at universal economic management by way of multinational principles, global development and awareness. $^{103}$

\footnotetext{
${ }^{98}$ Ibid.

${ }^{99}$ See Garett (2003).

${ }^{100}$ See UNCTAD (1999).

${ }^{101}$ See Baylis, Smith \& Owens (2008).

${ }^{102}$ See Martinussen (2004).

${ }^{103}$ See Hirst \& Thompson (1999) at 89.
} 
Transnational corporations can be categorised as the most important actors in the world economy in recent times. They have grown so quickly in size, occupying uninterrupted growing shares of global production, trade and services. It could be said that the interconnectedness of capital has greatly increased through these corporations. ${ }^{104}$ An estimate for 1980 put the number of TNCs at over 10,000 and the number of foreign affiliates at $90,000{ }^{105}$ By the early $1990 \mathrm{~s}$, according to another estimate, these numbers had risen to 35,000 and 170,000 respectively. ${ }^{106}$

The estimate of increase in 1998 was 60,000 transnational corporations including 500,000 external associates. The impact of TNCs is mostly felt in world investment, production, trade and technology transfers. ${ }^{107}$ The reports of the UNCTAD have shown among other things that TNCs have taken over international trade relations between the developed world and the developing countries. Although the exact proportion cannot be ascertained, more than half of the developing countries' exports to the Organisation for Economic Cooperation and Development (OECD) countries are regulated by large number of TNCs. ${ }^{108}$

The TNCs have a strong presence in the developing countries. They control important products in many economic sectors that have rare importance for the accumulation, growth and export of manufactured goods. ${ }^{109}$ Ohmae considers the trend towards TNCs to be well established. ${ }^{110} \mathrm{He}$ argues that such 'stateless corporations are now the prime movers in an interlinked economy centred on North America, Europe and Japan [...] macroeconomic and industrial policy intervention by national governments can only distort and impede the rational process of resource allocation by corporate decisions and consumer choices on a global scale. ${ }^{111}$ The TNCs have played both negative and prospective roles in Third World development. Amartya Sen widens the target of concentration on one aspect of development, the gross domestic product as a widely accepted measure of a nation's economic strength. ${ }^{112} \mathrm{He}$ argues that 'it is important not only to give markets their due, but also appreciate the role other economic, social and political freedoms in enhancing and enriching the lives that people are able to lead.' ${ }^{113}$ Sen agrees with Adam Smith that an unrestricted market is naturally good as it attracts increased wealth. ${ }^{114}$ The globalisation of a global economy will encourage economic growth, expansion of living standards and income which will definitely alleviate the suffering of the poor, although in the trend of financial crisis, globalisation can manifest itself as a double-edged sword, especially for countries that are not yet prepared to engage in competition with other countries.

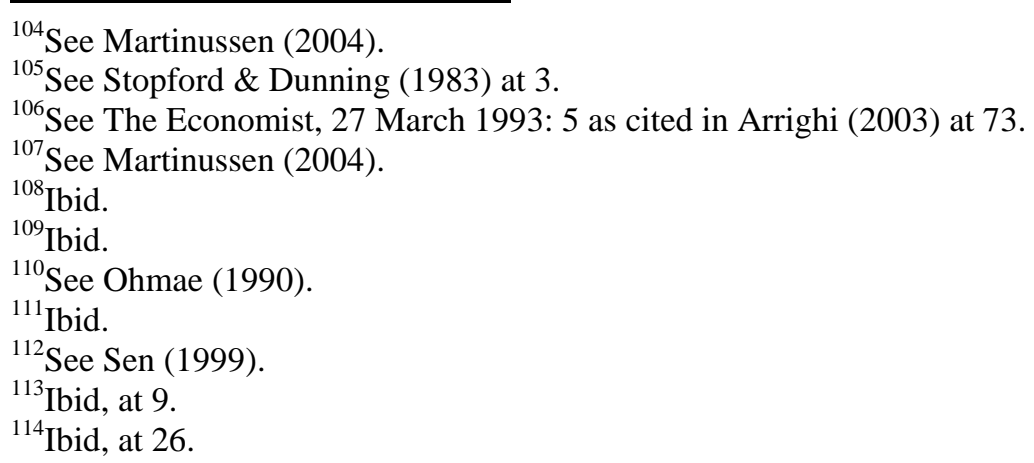


It should not be a case of competition among nations, but a matter of fairness and justice in the structuring of global economic policy to ensure just distribution of income. The unequal economic policy of the North remains unsettled and unfair towards developing countries. The logical assessment of it requires the understanding of justice and the conception of law. It has been argued that justice and legitimacy always create tension and ought to be 'managed' side by side. ${ }^{115}$ However, no solution has been offered on how these two competing ideas can be managed. Justice per se promotes change and is dynamic. In other words, 'justice exceeds law and calculation' and Derrida sees law as 'exceeding' justice. ${ }^{116}$ Law is law and only exceeds itself 'in the direction of' justice. ${ }^{117}$

Global economic policy in respect of developing countries must tilt towards the dimension of development. Ideally, developing countries will settle for distributive justice with legitimacy. In circumstances where preferences are to be made between the two, distributive justice would be preferred to legitimacy. ${ }^{118}$ Although a Rawlsian version of distributive justice alongside Dworkin and law could work in parallel, to obtain the fairness illustrated by Rawls requires the application of legal brilliance defended by Dworkin which maintains that law shall be founded on the socio-political values of the community. ${ }^{119}$ The main argument here is that the economic policy of the North must reflect the socio-political and cultural identity and economic values of the developing countries. The developing countries must not be seen only as potential economic enrichment factors by the North without considering their diversity as human beings. Karl Marx, in his 1875 critique of the Gotha Programme, subjected this kind of treatment to severe criticism. ${ }^{120}$ There should be increased participation by the developing nations in international economic regulation and increased voices in the socio-economic framework to ensure even development. This will offer a balanced legal structure for both national and international institutions and as well act as a catalyst to people in pursuit of global justice.

\section{Conclusion}

In this treatise we have highlighted that the developed nations' trade liberalisation and globalisation framework for global economic management is nothing but Western domination. The conceptual ideology of globalisation and liberalisation is infused with complexities, especially when applied to the South. Ordinarily, liberal ideology could have been a model for development if it were truly designed to serve the economic interests of all concerned. Against this background, there is glaring injustice, inequality and unfairness in its application. The interpretative basis of Rawls' idea of justice has not yet been attained to lift

\footnotetext{
${ }^{115}$ See Thomas (1995) at 147-160; Qureshi (2003) at 847.

${ }^{116}$ See Derrida (1992) at 28.

${ }^{117}$ Ibid, ibid.

${ }^{118}$ See Franck (1995) at 147-160

${ }^{119}$ See Dworkin (1986) at 31-44.

${ }^{120}$ See Marx (1875) at p. 9 of the 1938 English translation.
} 
the developing world from poverty. The most advocated development and economic growth for all participating countries through a liberal market is fraught with protectionism. However, it is unlikely that the introduction of the Bretton Woods system would bridge the socio-political and economic gap between the North and the South. This system was created as an institutional infrastructure that includes the principles of a liberal international economic order. It is proposed that the developing nations should speak with one voice and stand up against potential injustice.

\section{References}

Amin, S. (1974). The Accumulation of Capital on a World Scale. New York: Monthly Review Press.

Amin, S. (1977). Imperialism and Unequal Exchange. New York Monthly Review Press.

Alcock, A. (1971). History of the International Labour Organization. London: Macmillan.

Atlantic Charter 1941- Samuel Rosenman, ed; Public Papers and Addresses of Franklin Roosevelt, Vol. 10, 1938- 1950 at 314

Arrighi, G. (2000). The Long Twentieth Century. Verso Press.

Baylis, J. \& S. Smith. \& P. Owens. (2016). The Globalisation of World Politics: An Introduction to International Relations. Blackwell 2008.

Bello, W. (2002). Introduction: The Multiple Crisis of Global Capitalism. Chapter 1 in Deglobalization. New York: Zed Books.

Blair, D. H. (1988). 'The Primary-Goods Indexation Problem in Rawls Theory of Justice', in Theory and Decision, 24(3):239 -252.

Brawley, M.R. (2003). 'Defining Globalization', Chapter 1 in 'The Politics of Globalization - Gaining Perspective, assessing Consequences'. New York: Broadview Press.

Brown W.A. Jr.,(1950). The United States and the Restoration of World Trade. An Analysis and Approval of the ITO Charter and the General Agreement on Tariffs and Trade., Washington D.C; The Brookings Institute.

Brown, C. (2002). Sovereignty, Rights and Justice: International Political Theory Today. Cambridge: Polity Press.

Castells, M. (1996). The Information Age: Economy, Society and Culture: The Rise of the Network Society. First Edition, Volume I. Cambridge: Mass and Oxford, UK: Basil Blackwell. Volume II The Power of Identity. (1997). Basil Blackwell. and End of Millennium, (1998) Basil Blackwell. Volume III. Basil Blackwell.

Castells, M. (2010). The Information Age: Economy, Society and Culture: The Rise of the Network Society, Vol. I The Power of Identity. Vol. II and Vol. III, End of Millennium. Second Edition. London: Wiley - Blackwell.

Chang, H. J. (2007). 'Protectionism...The Truth is on a $\$ 10$ bill,' The Independent, 23 July. https://www.independent.co.uk/news/business/comment/ha-joon-chang-protec tionism-the-truth-is-on-a-10-bill-5334137.html accessed 24/08/2018

Charnovitz, S. (1995). 'Promoting Higher Labour Standards' in The Washington Quarterly 18(3):167-190.

Chase-Dunn, C. (1991). Global Formation, Structures of the World Economy. Oxford: Basil Blackwell.

Dasgupta, P. 'Globalisation of Law and Practices', ALMT Legal, Indo-European Consultants at http:www.legalserviceindia.com/articles/glp.htm, accessed 23/08/2018 
Derrida, J. (1992). 'Force of Law: The "Mystical Foundations of Authority', M. Quaintance (trans.), in D. Cornell, M. Rosenfeld \& D.G. Carlson (eds) Deconstruction and the Possibility of justice, New York: Routledge, pp. 3-67.

Douzinas, C. (2000). The End of Human Rights: Critical Legal Thought at the Turn of Century. Oxford: Hart Publishing.

Dur, A. (2007). 'Foreign Discrimination, Protection for Exports, and U.S. Trade Liberalization' in International Studies Quarterly 51(2): 457-480.

Dworkin, R. (1986). Law's Empire. London: Fontana.

Final Act of the United Nations Conference on Trade and Employment: Havana Charter for An International Trade Organization, Lake Success, New York, April, Art.1, 1948; Available at http://www.wto.org/english/docs_e/legal_e/havana_e.pdf

Franck, T.M. (1995). Fairness in International Law and Institutions. Oxford: Clarendon Press.

Frank, A.G. (1979). Dependent, Accumulation and Underdevelopment. New York: Monthly Review Press.

Frank, A.G. (1967). Capitalism and Underdevelopment in Latin America: Historical Studies of Chile and Brazil. New York: Monthly Review Press.

Frank, A.G. (1969). Latin America: Underdevelopment or Revolution - Essays on the Development of Underdevelopment and the Immediate Enemy. New York: Monthly Review Press.

Fukuyama, F. (1993). The End of History and the Last Man. London: Penguin.

Fukuyama, F. (2004). State-Building: Governance and World Order in the Twenty-first Century. New York: Profile Books..

Furtado, C. (1965). Diagnosis of the Brazilian Crisis. Berkeley: University of California Press.

Prebisch R. (1950). The Economic Development of Latin America and Its principal Problems. New York: United Nations.

Garett, G. (2003). 'Global Markets and National Politics: Collision Course or Virtuous Cycle?' Chapter 33 in D. Held \& A. McGrew (eds.) The Global Transformations Reader, $2^{\text {nd }}$ Edition. Cambridge: Polity.

Gilpin, R. (1987). The Political Economy of International Relations. Princeton University Press.

Havana Charter for an International Trade Organization (Havana Charter, ITO Charter 1948) United Nations [UN] UN DOC E/CONF.2/78, Article 7, 20, 21, 22, 34, 52, and 56.

Harvey, D. (2005). Brief History of Neoliberalism. Oxford: Oxford University Press.

Held, D. (2004). Global Covenant: The Social Democratic Alternative to the Washington Consensus. Cambridge: Polity.

Held, D. \& A. McGrew (2002). 'Making Sense of Globalization'. Chapter 1 in Globalization/Anti-globalization. Cambridge: Polity.

Held, D. \& A. McGrew (2003). 'The Great Globalization Debate: An Introduction', in The Global Transformation Reader, $2^{\text {nd }}$ Edition, Cambridge: Polity.

Held, D., McGrew, A. Golblatt, D. \& J. Perraton (1999). 'Shifting Patterns of Global Finance'. Chapter 4 in Global Transformations. Cambridge: Polity.

Hirst, P. (1997).' The global economy: Myths and Realities' in International Affairs 73(3); 409-425.

Hirst, P. \& G. Thompson (1996). Globalization in Question. Cambridge: Polity.

Hobson, J. (1902). Imperialism: A Study. New York: J. Pott \& Company

Hoeffmann, S. (1981). Duties Beyond Borders. Syracuse, NY: Syracuse University Press.

Holton, R.J. (1998). Globalisation and the Nation-State. Pelgrave Macmillan. 
Hoogvelt, A. (2001). Globalization and the Post Colonial World: The New Political Economy of Development. $2^{\text {nd }}$ ed. Pelgrave Macmillan

Hudec, R.E. (1999). 'The New WTO Dispute Settlement Procedure: An Overview of the First Three Years' in Minnesota Journal of Global Trade 8:1-53

Irwin, D.A. (2001). 'Tariffs and Growth in late Nineteenth Century America' in The World Economy 24:15-30.

Jackson, J.H. (1989). The Word Trade System: Law and Policy of International Economic Relations. Cambridge, Mass: MIT Press.

Jackson, J.H. (1992). GATT and the Future of International Trade Institutions. In Brooklyn Journal of International Law', 8(3):11.

Jackson, J.H. (1994). Testimony in the World Trade Organisation and United States Sovereignty Hearing Before the United States Senate Committee on Foreign Relations, 994 WL 266992, June 4.

Stopford, J.M. \& J.H. Dunning (1983). Multinationals: Company Performance and Global Trends. London: Macmillan.

Watkins, K. (1992). Fixing the Rules: North-South Issues in International Trade and GATT Uruguay Round. Catholic Institute for International Relations.

Kock, K. (1969). International Trade Policy and the GATT 1947-1967. Stockholm: Almqvist and Wiksell.

Lenin, V.I. (1917). Imperialism: The Highest Stage of Capitalism, London: Pluto Press (1996).

Lipson, C. (1985). Standing Guard', Protecting Foreign Capital in the Nineteenth and Twentieth Century. Berkeley: University of California Press.

Maddison, A. (2003). The World Economy, Vol 2: Historical Statistics. Paris: Organization for Economic Co-operation and Development (OECD).

Magdoff, H. (1972). 'Imperialism Without Colonies' in Roger Owen and Bob Sutcliffe (eds.) Studies in the Theory of Imperialism. New York: Monthly Review Press.

Magdoff, H. (1978). Imperialism: From the Colonial Age to the Present. New York: Monthly Review Press.

Mandel, E. (1976). Late Capitalism. London: New Left Books.

Mandle, J. (2000). 'Globalization and Justice' in The Annals of the American Academy of Political \& Social Science 570: 126-139..

Martinussen, J. (2004). Society, State and Market, a guide to Competing Theories of Development. Pretoria: HSRC Publishers

Marx, K. (1938). Critique of the Gotha Programme.[1875], English translation in K. Marx and F. Engels, New York: International Publishers.

Marx, K. \& F. Engels. (1980). Collected Works. New York: International Publishers.

McCornick, T. J. (1989). America's Half Century United States Foreign Policy in the Cold War. Baltimore, MD: Johns Hopkins University Press.

McLuhan, M. (1962). The Gutenberg Galaxy: The Making of Typographic Man. Toronto: University of Toronto Press.

McLuhan, M. (1964). Understanding Media. Corte Madera, Cal: Gingko Press.

McLuhan, M. (2003). Understanding Media: The Extension of Man', Critical Edition. W. Terrence Gordon (ed), Corte Madera, Cal: Gingko Press.

Ohmae, K. (1990). The Borderless World: Power and Strategy in the Interlinked Economy. New York: McKinsey \& Company.

Ohmae, K. (2004). 'The End of the Nation State'. Ch. 26 in F. Lechner and J. Boli (eds.) The Globalization Reader, $2^{\text {nd }}$ Edition. Oxford: Blackwell.

Peet, R. \& E. Hartwick (1999). Theories of Development. New York: Guilford Publications. 
Perraton, J., Goldblatt, D, Held, D. \& A. McGrew (1997). 'The Globalisation of Economic Activity' in New Political Economy 2(2):257-277.

Pogge, T. W. (1989). Realizing Rawls. Ithaca, New York: Cornell University Press.

Polanyi, K. (1944). The Great Transformation - The Political and Economic Origin of Our Time. Boston: Beacon Press.

Qureshi, A. (2003). 'Interpreting World Trade Organisation Agreement for the Development Objective' in Journal of World Trade 37(5):847-882.

Rawls, J. (1971). A Theory of Justice. Cambridge, Massachusetts: Harvard University Press.

Rawls, J. (2001). Justice as Fairness: A Restatement. Harvard University Press.

Rawls, J. (2005). Political Liberalism. Columbia University Press.

Rosenberg, J. (2001). The Follies of Globalization Theory. London: Verso.

Ruggie, J.G. (1982). 'International regimes, transactions, and change: embedded liberalism in the postwar economic order' in International Organisation 36(2): 379-415.

Sen, A. (1991). On Indexing Primary Goods and Capabilities. Mimeographed. Harvard University Press.

Sen, A. \& J. Foster (1997). On Economic Inequality enlarged with a substantial annexe on Economic Inequality after a Quarter Century. Oxford: Clarendon Press.

Stichele, M.V. (1996). The Ministerial Conference in Singapore and the Developing Countries. WTO Booklet Series, Vol. 1, 8 November.

Schurmann, F. (1974). The Logic of World Power, An Inquiry into the Origins, Currents and Contradictions of World Politics. New York: Pantheon.

Thomas, C. (1987). In search of security: The Third World in International Relations/

Hertfordshire: Wheatsheaf Books Ltd.

Thomas, C. (1997). In search of security: The Third World Understanding International Relations. $1^{\text {st }}$ Edition, London: Macmillan.

UNCTAD: (1999). United Nations Conference and Development. World Investment Report 1999. Foreign Direct Investment and challenges of Development. UN: New York and Geneva.

Vandana, S. (2004). 'Ecological Balance in an Era of Globalization', Chapter 55 in F. Lechner and J. Boli, (eds.) The Globalization Reader. Oxford: Blackwell.

Viner, J. (1947), 'Conflicts of Principles in Drafting a Trade Charter' in Foreign Affairs 25(4): 612-628.

Wallerstein, I. (1976). The Modern World-System: Capitalist Agriculture and the Origins of the European World-Economy in the Sixteenth Century. New York: Academic Press.

Wallerstein, I. (1979). The Capitalist World-Economy. Cambridge: Cambridge University Press.

Wallerstein, I. (1980). The Modern World System II: Mercantilism and the Consolidation of the European World Economy, 1600-1750. New York: Academic Press.

Wallerstein, I. (2004). The Modern World-System as a Capitalist World-Economy in World-Systems Analysis: An Introduction. Duke University Press.

Wallerstein, I. (2005). World - System Analysis: An introduction. Duke University Press.

Waltz, K. (1979). The Theory of International Politics. New York: Addison Wesley.

Walzer, M. (1992). Just and Unjust Wars', A Moral Argument with Historical Illustrations, $2^{\text {nd }}$ Edition. New York: Basic Books.

Wolf, M. (2004). Why Globalisation Works. New Haven and London: Yale University Press.

Woodward, R. (2007). Neo-Liberalism, State Power and Global Governance. Springer Netherlands.

Wilcox, C. (1949). A Charter for World Trade. New York: Macmillan. 
Wilkinson, R. (2006). The WTO: Crisis and the Governance of Global Trade. London: Routledge.

Wilkinson, R. (2009). 'Language, Power and Multilateral Trade Negotiations' in Review of International Political Economy 16(4):567-619. 